\title{
Formulasi Ransum Untuk Itik Indukan Di Gapoktan Desa Purwokerto Kecamatan Brangsong Kabupaten Kendal
}

\author{
L. Krismiyanto ${ }^{1}$, Mulyono, $\mathrm{N}^{2}$. Suthama, $\mathbf{I}^{3}$. Mangisah, $\mathbf{F}^{4}$. Wahyono, \\ B. Sukamto ${ }^{5}$ dan V. D. Yunianto \\ Departemen Peternakan, Fakultas Peternakan dan Pertanian, Universitas Diponegoro, \\ Jln. Drh. R. Soejono Koesoemowardojo Tembalang, Semarang \\ Email: lilikkrismiyanto@gmail.com
}

\begin{abstract}
ABSTRAK
Tujuan pengabdian adalah untuk memberikan pengetahuan kepada peternak itik indukan di Gapoktan Desa Purwokerto Kecamaran Brangsong Kabupaten Kendal tentang manajemen pemeliharaan, cara formulasi ransum, pengenalan bahan pakan inkonvensional dan bahan aditif seperti prebiotik/probiotik/makromineral. Itik Pebibit atau indukan memiliki peran terpenting untuk menghasilkan produk day old duck (DOD) baik itik pedaging atau petelur. Itik indukan harus memerlukan pemeliharaan intensif untuk memperoleh hasil yang bagus. Manajamen pakan melalui formulasi ransum harus diperhatikan keberadaan atau ketersediaan bahan pakan, kebutuhan nutrien dan kandungan nutrin bahan pakan. Metode yang digunakan pada kegiatan pengabdian ini adalah penyuluhan, praktek dan pendampingan. Kegiatan dilakukan dengan kerjasama dengan Gapoktan yaitu kelompok peternak itik indukan di Desa Purwokerto Kecamatan Brangsong Kabupaten Kendal. Masing-masing pihak memberikan kontribusi untuk terlaksananya kegiatan. Luaran kegiatan adalah peningkatan pengetahuan dan ketrampilan peternak dalam manajemen itik indukan, khususnya dalam formulasi ransum dan pengenalan bahan pakan berdasarkan sumbernya.
\end{abstract}

Kata kunci: Itik Indukan, Ransum, Gapoktan

\begin{abstract}
The purpose is to provide knowledge to the farmer of duck breeders in Gapoktan, Purwokerto Village, Brangsong District, Kendal Regency regarding maintenance management, method of ration formulation, the introduction of unconventional feed ingredients and additives such as prebiotic/probiotics/macromineral. Breeder ducks have the most important role in producing day-old duck (DOD) products, either broiler or laying ducks. Breeder ducks must require intensive maintenance to obtain good results. Feed management with ration formulation must consider the presence or availability of feed ingredients, nutrient requirements and nutrient content of feed ingredients. The methods used in this service are counselling, practice and mentoring. The activity was carried out in collaboration with Gapoktan, namely the group of broodstock breeders in Purwokerto Village, Brangsong District Kendal Regency. Each party contributes to the implementation of activities. The output of the activity is to increase the knowledge and skills of breeders in the management of broodstock ducks, especially in the formulation of rations and introduction of feed ingredients based on the source.
\end{abstract}

Keywords: Breeder Ducks, Ration, Gapoktan. 


\section{PENDAHULUAN}

Itik merupakan sumber protein hewani yang mampu menyumbangkan daging dan telur untuk memenuhi kebutuhan protein hewani masyarakat. Selain ayam ras maupun ayam lokal, itik juga berpeluang untuk dikembangkan karena produk daging dan telur memiliki kandungan gizi yang hampir sama dengan ayam ras atau lokal. Populasi itik di Jawa Tengah dari tiga tahun terkhir (2016-2018) mengalami kenaikan 29,69\% (4.953.832-6.681.229 ekor) (Direktorat Jenderal Peternakan dan Kesehatan Hewan, 2018). Hampir itik di Jawa Tengah masih dipelihara secara tradisional.

Itik menyumbangkan kebutuhan telur sebanyak 16\% sama dengan ayam kampung. Peningkatan produksi itik dapat dilakukan dengan perbaikan ransum yang selama ini masih diberikan pakan apa adanya. Penyediaan bahan pakan sesuai dengan kebutuhan nutrien dapat meningkatkan produktivitas. Selain itu juga harus didukung dengan manajemen pemeliharaan, yang selama ini pemeliharaanya masih digembalakan di sawah. Pembinaan terhadap peternak perlu didampingi terus sampai peternak bisa merubah sistem pemeliharaan yang semula tradisional menjadi intensif. Pemeliharaan itik secara tradisional maupun intensif dapat berdampak terhadap produksi telur atau daging.

Pemberian pakan itik peternak berupa konsentrat dan menghandalkan sisa hasil panen padi. Sistem pakan tersebut yang menjadi kendala peternak yang produksi telur atau dagingnya tidak stabil. Pemeliharaan secara intensif dapat digunakan ransum berupa konsentrat, nasi aking dan bekatul atau dedak padi. Ketiga bahan pakan tersebut dapat memberikan produktivitas yang bagus dibandingkan digembalakan. Berdasarkan hasil penelitian Ketaren (2006) bahwa itik pedaging yang diberikan ransum dengan dedak padi sampai $72,5 \%$ tidak mengganggu penampilan performansnya. Selain itu, dalam penyusunan ransum dapat ditambahkan juga makromineral, probiotik, prebiotik dan premiks. Pemberian bahan tersebut dapat memberikan penampilan produksi yang optimal.

Berdasarkan survei di lapangan dan hasil diskusi dengan anggota kelompok dan pemerintah daerah setempat, maka dapat dirumuskan masalah prioritas yang perlu ditangani oleh tim pengabdian, antara lain :

1. Usaha peternakan itik indukan di Gapoktan Desa Purwokerto Kecamaran Brangsong Kabupaten Kendal masih bersifat tradisional sehingga hasilnya belum optimal.

2. Manajemen pakan atau ransum yang diberikan tidak optimal.

3. Rendahnya informasi pemanfaatan bahan pakan inkonvensional dan aditif

4. Harga pakan yang cenderung mahal.

Tujuan kegiatan pengabdian ini adalah memberikan pengetahuan kepada peternak itik indukan di Gapoktan Desa Purwokerto Kecamaran Brangsong Kabupaten Kendal tentang manajemen pemeliharaan, cara formulasi ransum, pengenalan bahan pakan inkonvensional dan bahan aditif seperti prebiotik/probiotik/makromineral.

Kegiatan pengabdian kepada masyarakat diharapkan dapat memberikan manfaat kepada peternak dalam menerapkan manajemen perencanaan yang efisien dan produktif, seperti manajemen pemeliharaan, penyusunan ransum, pengenalan bahan pakan inkonvensional dan bahan aditif.. 


\section{METODE}

Metode yang digunakan dalam kegiatan pemecahan masalah ini adalah :

1. Kegiatan pendidikan dan penyuluhan.

Penyuluhan dengan materi : manajemen pemeliharaan, cara formulasi ransum, pengenalan bahan pakan inkonvensional dan bahan aditif seperti prebiotik/probiotik/makromineral.

2. Kegiatan praktek

Praktek formulasi ransum dijelaskan terlebih dahulu jenis-jenis sumber nutrien pada bahan pakan. Bahan pakan yang sudah diketahui sumbernya diformulasikan secara manual. Proses pencampuran bahan pakan dimulai dari bahan pakan yang jumlahnya banyak sampai bahan yang sedikit, contohnya bahan dari makromineral.

Pemantauan dan pendampingan dilakukan dua mingu sekali oleh Tim Pelaksana selama kegiatan.

Kegiatan pengabdian yang dilakukan, masyarakat peternak berperan aktif dalam kegiatan tersebut dan memberikan kontribusi antara lain :

1. Kegiatan penyuluhan pada masyarakat peternak menyediakan lokasi, sarana dan prasarana kegiatan. Sedangkan tim pengusul menyediakan instruktur yang berpengalaman dan modul penyuluhan.

2. Kegiatan praktek pada peternak berkontribusi menyediakan bahan pakan dan tenaga. Tim pengabdian menyediakan instruktur, juga menyediakan aditif (makromineral/prebiotik/probiotik). Instruktur melatih cara formulasi ransum dalam skala kecil terbelih dahulu.

\section{HASIL, PEMBAHASAN, DAN DAMPAK}

Materi yang diberikan dalam bentuk ceramah yaitu menjelaskan teknik penyusunan ransum pada itik indukan, manajemen pemberian pakan dan fungsi bahan aditif atau makromineral. Peternak itik indukan dibekali cara penyusunan ransum yang efisien atau tidak mahal. Pakan komersil khusus itik harganya relatif mahal sehingga menghambat produksi telur. Langkah peternak yang harus ditempuh adalah memanfaatkan bahan pakan yang ada di sekitar, mengoptimalkan by product pertanian dan harga bahan pakan tidak tinggi.

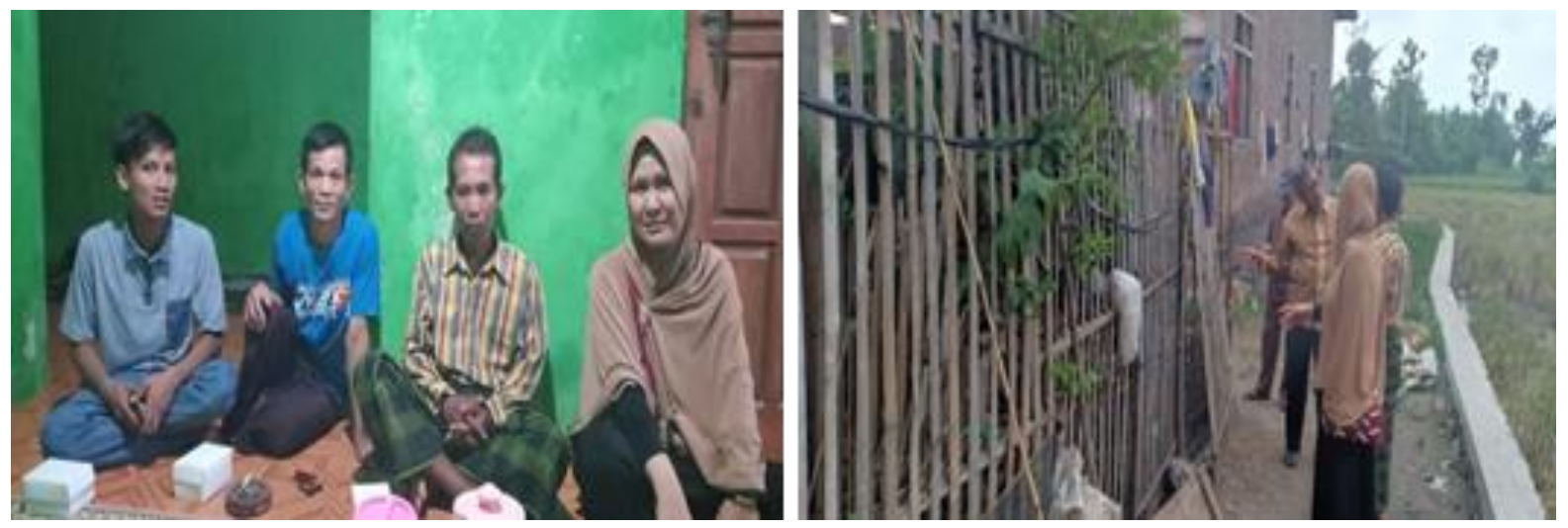

Gambar 1. Penyampaian Materi Peternak Gapoktan Purwokerto Brangsong 
Peternak harus memahami teknik penyusunan ransum. Hal-hal yang harus diperhatikan dalam penyusunan ransum meliputi:

1. Kebutuhan nutrisi ternak

2. Kadar nutrisi bahan pakan yang akan digunakan untuk formulasi ransum

3. Memilih bahan pakan yang ada di sekitar lingkungan

4. Bahan pakan tidak bersaing dengan manusia

5. Bahan pakan tidak mengandung racun

Adapun teknik penyusunan ransum sebagai berikut:

1. Menentukan kebutuhan nutrisi ternak.

2. Menentukan kadar nutrisi bahan pakan.

3. Memilih bahan pakan yang ada di sekitar lingkungan dan ketersediaan jangka panjang.

4. Menentukan komposisi bahan pakan.

5. Memasukkan ke dalam perhitungan Microsoft excel atau menghitung manual.

6. Kadar nutrisi masing-masing bahan pakan dikalikan dengan komposisi bahan pakan.

7. Menjumlahkan hasil perkalian kadar nutrisi bahan pakan dan komposisi tersebut.

Bahan pakan untuk penyusunan ransum itik indukan harus memperhatikan kebutuhan nutrisi itik. Kadar nutrisi itik indukan meliputi energi metabolis $2.650 \mathrm{kkal} / \mathrm{kg}$, minimal protein kasar 17\%, lemak kasar 3\%, serat kasar maksimal 10\%, kalsium 2,9-4,25\% dan fosfor 0,55\% (Badan Standar Nasional, 2017). Bahan pakan yang digunakan untuk contoh formulasi ransum peternak itik indukan Gapoktan meliputi jagung giling, dedak padi, bungkil kedelai, keong sawah dan premik. Keong sawah digunakan untuk formulasi ransum, karena keberadaan keong sawah yang melimpah terutama pada musim penghujan. Adapun keong sawah juga mengganggu tanaman padi, sehingga dapat memanfaatkan bahan tersebut. Keong sawah termasuk bahan pakan sumber protein hewani yang dapat menyumbangkan protein pada bahan tersebut. Selain itu, keong sawah memiliki kadar asam amino cukup baik mendekati kadar asam amino pada tepung ikan lokal. Listiana dan Isworo (2012) melaporkan bahwa kadar protein keong sawah sebesar 51,8\% dan kadar protein tepung ikan lokal sebesar 53,5\% (Baye et al., 2015). Peternak dengan memanfaatkan bahan pakan by product dapat menurunkan penggunaan pakan pabrikan yang relatif mahal. Pemanfaatan by product atau bahan inkonvensional dapat memperbaiki kualitas pakan yang efisien.

Peternak dalam ransum harus ada pakan tambahan berupa premik, karena premiks memiliki kadar mineral mikro atau mako dan vitamin yang mampu meningkatkan produksi telur. Contoh premik seperti probiotik, prebiotik dan acidifier. Probiotik adalah bakteri hidup yang diberikan ke ternak bermanfaat bagi saluran pencernaan dan menekan pertumbuhan bakteri patogen sehingga dapat meningkatkan kecernaan nutrisi. Contoh probiotik meliputi Lactobacillus sp., Bacillus sp., dan Bifidobacterium. Prebiotik adalah substrat "makanan" bagi bakteri menguntungkan dan mampu meningkatkan saluran pencernaan. Contoh prebiotik meliputi inulin, soybean oligosakarida, fruktooligosakarida, mannan oligosakarida dll. Acidifier merupakan senyawa asam organik yang berfungsi untuk menurunkan $\mathrm{pH}$ saluran 
pencernaan. Penggunaan acidifier dalam pakan dapat meningkatkan aktivitas enzim-enzim protease, utamanya pepsin. Pepsinogen aktif menjadi pepsin dalam kondisi asam. Peternak dengan mengetahui penggunaan bahan premik dan aditif (probiotik, prebiotik dan acidifier) mampu mengenal bahan tambahan yang dapat digunakan dalam campuran pakan. Karena penggunaan bahan tersebut perlu dibutuhkan dalam pakan untuk meningkatkan produktivitas.

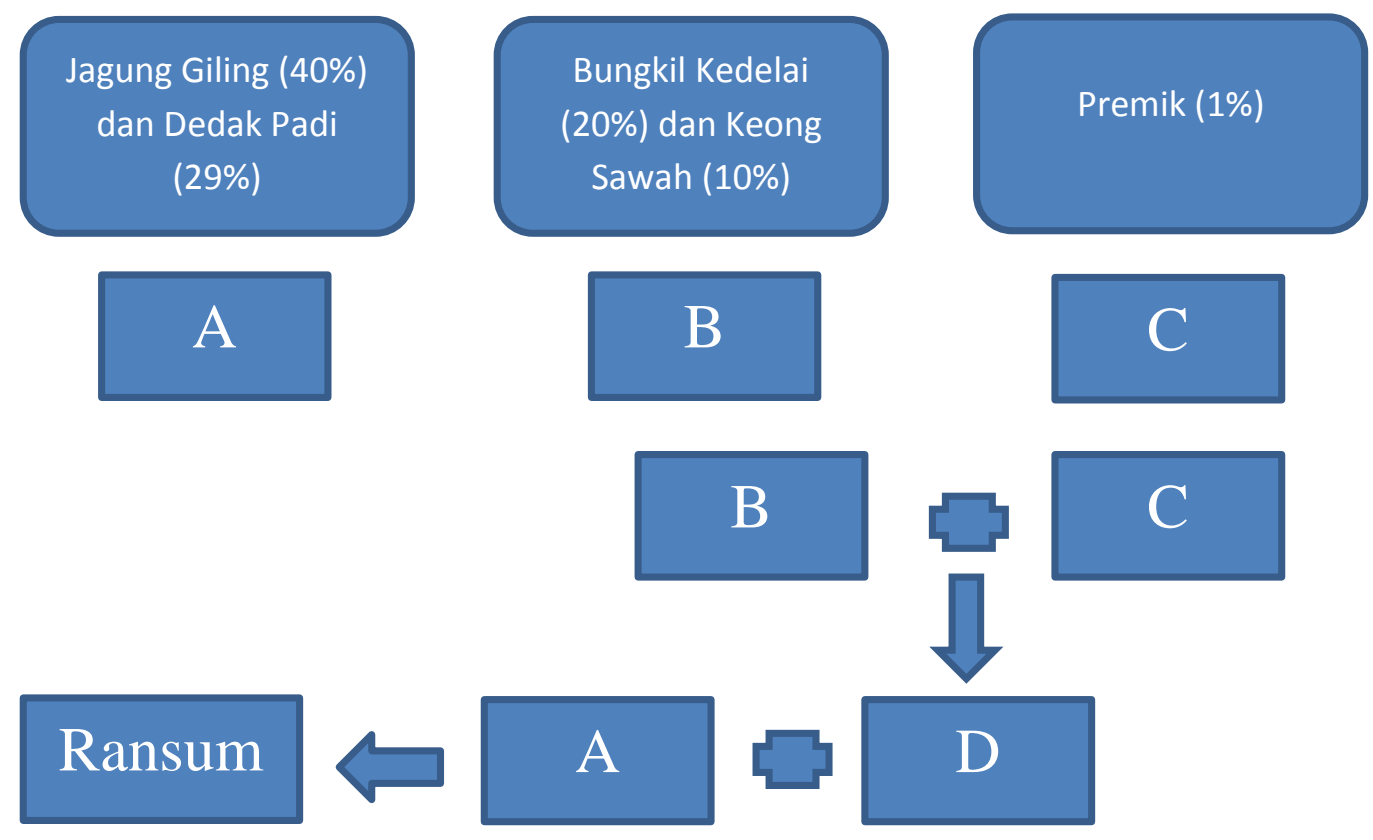

Gambar 2. Proses Pencampuran Bahan Pakan menjadi Ransum

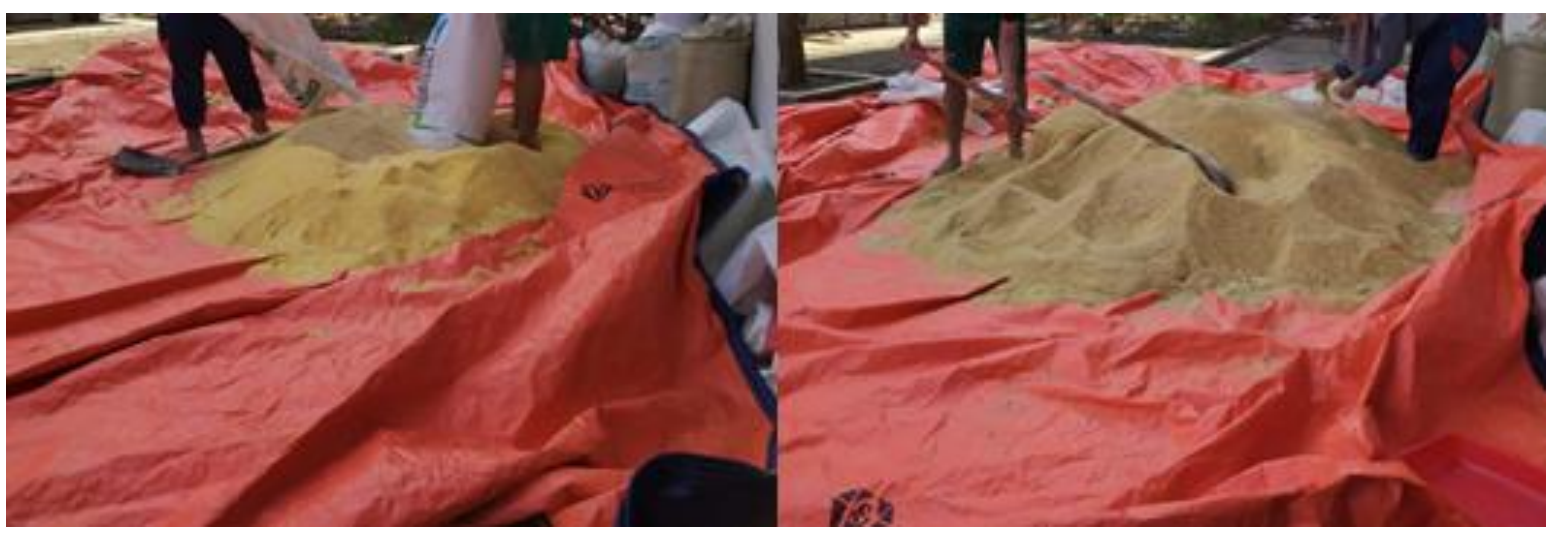

Gambar 3. Formulasi Ransum untuk Itik Indukan

Manajemen pemberian pakan perlu diperhatikan yang selama ini pakan diberikan dalam bentuk basah. Pakan itik indukan perlu diubah ke pemeliharaan secara semi intensif. Pakan diberikan dalan bentuk kering dan air minum terpisah dari tempat pakan. Tujuan dilakukan pemberian pakan kering agar pakan tidak mudah basi dan berjamur. Pemberian air yang libitum agar itik tidak mengkonsumsi air dalam jumlah banyak sehingga ekskreta tidak encer. Hasil dari penjelasan formulasi pakan dan praktek dapat memberikan motivasi peternak cara penyusunan pakan yang baik dan pemilihan bahan pakan inkonvensional atau 
by product. Penyampaian materi tentang manajamen pakan peternak dapat mengetahui perbedaan cara pemberian pakan yang efisien dan menjaga kondisi kandang yang sehat.

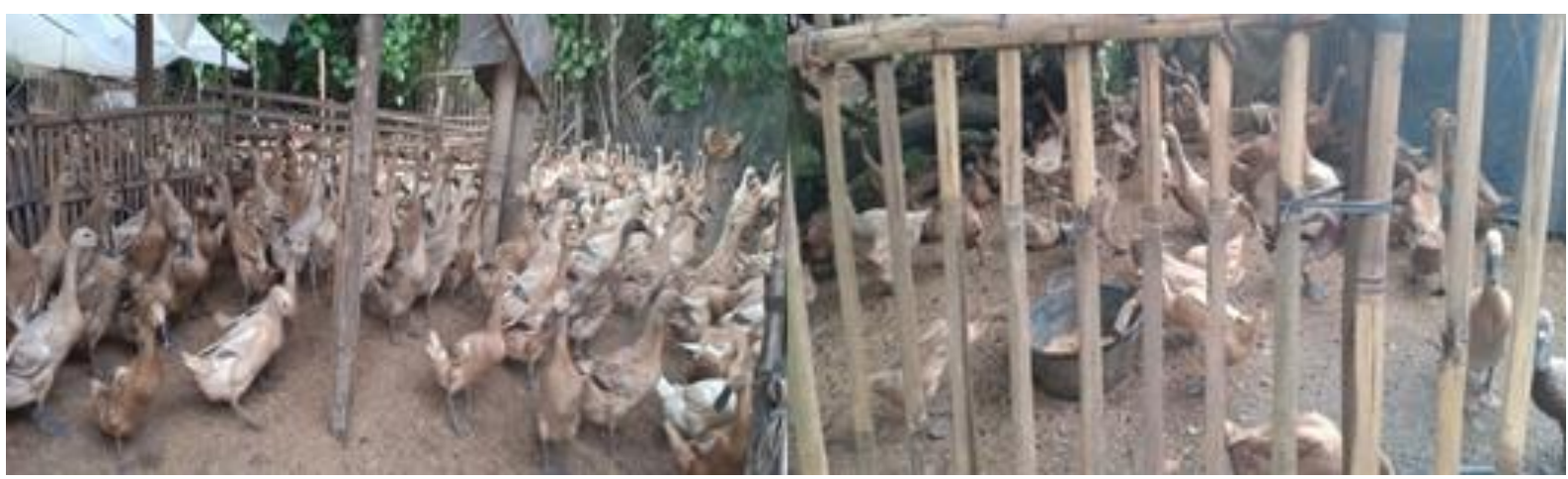

Gambar 4. Pemeliharan Itik Indukan Gapoktan

\section{SIMPULAN}

Berdasarkan pembahasan diatas dapat disimpulkan bahwa para peternak itik indukan sangat antusias dan respon selama kegiatan pengabdian, peternak mendapatkan banyak informasi mengenai penyusunan ransum dan manajemen pemberian ransum, serta menambahkan keterampilan dan kemampuan peternak itik indukan.

\section{UCAPAN TERIMAKASIH}

Ucapan terimakasih ditujukan kepada Fakultas Peternakan dan Pertanian Universitas Diponegoro atas dana hibah yang mendukung kegiatan pengabdian masyarakat.

\section{DAFTAR PUSTAKA}

Badan Standar Nasional. 2017. Pakan Itik Petelur Masa Produksi (Duck layer). Standar Nasional Indonesia, Jakarta.

Baye, A., F. N. Sompie, B. Bagan dan M. Regar. 2015. Penggunaan tepung limbah pengalengan ikan dalam ransum terhadap performa broiler. J. Zootek 35(1):96-105.

Direktorat Jenderal Peternakan dan Kesehatan Hewan. 2018. Populasi Itik/Itik Manila. Badan Pusat Statistik, Jakarta.

Ketaren, P. P. 2006. Pengaruh suplementasi enzim ke dalam pakan mengandung dedak tinggi terhadap performan itik pedaging. Pros. Seminar Nasional Bioteknologi. Cibinong, 1516 Nopember 2006. Puslit Bioteknologi, LIPI, Cibinong. Hlm. 134-139.

Listiana, T. dan T. Isworo. 2012. Sifat fisik, kimia dan organoleptic nugget keong sawah dengan bahan pengisi pati temu ireng. J. Pangan dan Gizi 3(5):21-27. 